HEMOGLOBIN

Vol. 28, No. 3, pp. 267-271, 2004

\title{
The $\beta$-Globin Gene Cluster Haplotypes in Sickle Cell Anemia Patients from Northeast Brazil: A Clinical and Molecular View
}

\author{
Elisângela Vitória Adorno, ${ }^{1,2}$ Ângela Zanette, ${ }^{3}$ Isa Lyra, ${ }^{3}$ \\ Cyntia Cajado Souza, ${ }^{1}$ Leandro Ferraz Santos, ${ }^{1,2}$ \\ Joelma Figueiredo Menezes, ${ }^{1}$ Marie France Dupuit, ${ }^{2}$ \\ Mari Ney Tavares Almeida, ${ }^{2}$ Mitermayer Galvão Reis, ${ }^{1}$ \\ and Marilda Souza Gonçalves ${ }^{1,2, *}$ \\ ${ }^{1}$ Laboratório de Patologia e Biologia Molecular, Centro de Pesquisas Gonçalo Moniz, \\ Fundação Oswaldo Cruz (FIOCRUZ), Salvador-Bahia, Brazil \\ ${ }^{2}$ Universidade Federal da Bahia, Campus Universitário de Ondina, \\ Salvador-Bahia, Brazil \\ ${ }^{3}$ Ambulatório de Hematologia, Fundação de Hematologia e Hemoterapia da Bahia \\ (HEMOBA), Salvador-Bahia, Brazil
}

\begin{abstract}
The $\beta^{\mathrm{S}}$-globin haplotypes were studied in 78 sickle cell Brazilian patients from Bahia, Northeast Brazil, that has a large population of African origin. Hemoglobin $(\mathrm{Hb})$ profiles were developed by high-performance liquid chromatography (HPLC), and $\beta^{S}$-globin gene haplotypes were determined by polymerase chain reaction-restriction fragment length polymorphism (PCR-RFLP) techniques. We identified 44 (55.0\%) patients with the CAR/Ben (Central African Republic/Benin) genotype, 16 (20.0\%) Ben/Ben, 13 (16.2\%) CAR/CAR and seven (8.8\%) with other genotypes. Analyses
\end{abstract}

\footnotetext{
*Correspondence: Dr. Marilda Souza Gonçalves, Laboratório de Patologia e Biologia Molecular, Centro de Pesquisas Gonçalo Moniz, Fundação Oswaldo Cruz (FIOCRUZ), Rua Waldemar Falcão 121, Brotas, Salvador-Bahia, CEP: 40.295-001, Brazil; Fax: +55-71-356-2155; E-mail: mari@ cpqgm.fiocruz.br.
} 


\begin{abstract}
of the phenotypes showed clinical differences related only to $\mathrm{Hb} \mathrm{F}$ levels and blood transfusion therapy; the presence of $-\alpha^{-3.7}$-thalassemia (thal) demonstrated statistical significance when associated with hematocrit $(p=0.044)$, MCV ( $p=0.0007), \mathrm{MCH}(p=0.012)$ and spleen sequestration events. The haplotype diversity found in the present study can be justified by information about the origin of the slave traffic period in Bahia during the 19th century. The specific characteristics described among the Bahian sickle cell patients could be confirmed by increasing the number of patients with specific genotypes and further studies of genetic markers.
\end{abstract}

Key Words: $\quad \beta$-Globin haplotypes; Sickle cell anemia; Northeast Brazil; Slave trade.

The $\beta^{\mathrm{S}}$-globin gene haplotypes are named according to the geographic areas where they predominate and are useful in the definition of African population origins (1). They have been classified as five different types: the Benin (Ben) has been associated with Midwestern Africa; the Bantu or Central African Republic (CAR) with South-Central and Eastern Africa; the Senegal (Sen) with Atlantic West Africa, the Arab-Indian type with the Indian subcontinent and Eastern Arabian Peninsula, and the Cameroon (Cam) along the west coast of Africa $(1,2)$. The Senegal haplotypes have been associated with high $\mathrm{Hb} \mathrm{F}$ levels and a less severe clinical course, the Benin haplotype with an intermediate clinical course and $\mathrm{Hb} \mathrm{F}$ levels, and the Central African Republic haplotype with a low $\mathrm{Hb} F$ level and a more severe clinical course $(2,3)$. The Arab-Indian haplotype presents the highest $\mathrm{Hb} \mathrm{F}$ levels with a heterogeneous clinical course (4).

Brazil is the largest country of South America and has a population with a high rate of racial admixture with a strong compound of African genes that were introduced by the slave trade (5). The country has a high prevalence of hemoglobin $(\mathrm{Hb})$ disorders, with the South presenting a frequency of $6.6 \%$ sickle cell trait ( $\mathrm{Hb} \mathrm{AS})$ in a Black population (6), and the Bahia state, located in Northeast Brazil, with a frequency of $7.5 \%$ to $15.7 \%$, when different groups of this population were studied (7). In the present study, we investigated the $\beta^{\mathrm{S}}$-globin gene haplotypes in 80 sickle cell anemia patients from the Blood Center of Bahia State, in order to confirm the African origin of this population.

The $\mathrm{Hb}$ profile was obtained by high-performance liquid chromatography (HPLC) (VARIANT $\mathrm{II}^{\mathrm{TM}}$; Bio-Rad Laboratories, Hercules, CA, USA) and the DNA was isolated from peripheral blood leukocytes by the GFX ${ }^{\mathrm{TM}}$ Genomic Blood DNA Purification KIT (Amersham Pharmacia Biotech, Piscataway, NJ, USA). The $\beta^{\mathrm{S}}$-globin gene haplotypes were investigated by polymerase chain reaction (PCR) and the haplotype polymorphic sites identified by restriction fragment length polymorphism analysis (RFLP) as previously described (8).

Among the $160 \beta^{\mathrm{S}}$ chromosomes analyzed, 78 (48.8\%) were characterized as the Benin type, 74 (46.2\%) Central African Republic, three (1.9\%) Cameroon, one (0.6\%) Arab-Indian, one $(0.6 \%)$ Senegal and three $(1.9 \%)$ were characterized as other haplotypes. The genotype characterization showed 44 (55.0\%) CAR/Ben, 16 (20.0\%) Ben/Ben, $13(16.2 \%)$ CAR/CAR and seven (8.8\%) classified as other genotypes. Statistical significance for use of blood transfusion therapy occurred more frequently in 
patients with $\mathrm{Hb} \mathrm{F}$ levels below 10.0\% ( $p=0.0015)$; statistical differences were observed for hematocrit $(p=0.044), \operatorname{MCV}(p=0.0007), \mathrm{MCH}(p=0.012)$ and the spleen sequestration events $(p=0.032)$ among $-\alpha^{-3.7}$-thal carriers, according to other studies $(9,10)$.

In this study, the Benin haplotype frequency (48.8\%) was slightly higher than the Central African Republic haplotype (46.2\%), and the prevalence of the CAR/Ben genotype $(54.0 \%)$ was consistent with the results described by Gonçalves et al. (11) who studied the $\beta^{\mathrm{S}}$-globin gene haplotypes among sickle cell disease patients from Salvador-Bahia, Brazil. The slave trade in Brazil was extensively reported by Curtin (12) who described Brazil as the largest, single importer into the Americas. The information from the British and Brazilian government offices described uncertainty about the Brazilian imports during the 1820s and 1830s, with a total of 8000 slaves of unknown origin imported into Bahia in the 19th century between 1817 and 1843, justifying the presence of the Cameroon, Senegal and Arab-Indian haplotypes found in the present study (12).

These results are different from those observed among other American countries, confirming the diversity of the African influence in Bahia. The United States of America and Jamaica received slaves from Midwestern Africa during the British Atlantic slave trade, where the Benin haplotype is more prevalent. However, in Mexico (Costa Chica region), Colombia, Central-Western regions of Venezuela, Cuban and Puerto Rican regions, there is a predominance of the Central African Republic haplotype, suggesting a different African origin for these populations (13-15).

The results described in Bahia are different from other regions of Brazil, such as the southeast and north, where there is a predominance of the CAR $\beta^{S}$-globin gene haplotypes of $66.2 \%$ and $66.7 \%$, respectively, demonstrating the heterogeneity of the African slave trade brought to the country $(16,17)$. These results indicate a contribution of Africans from Congo, Mozambique and Angola, where the CAR haplotype is predominant, that received ships from Bahia with tobacco and returned with slaves; this slave trade was intensified between 1815 and $1824(18,19)$. Nevertheless, there is evidence that the northeastern region of Brazil, mainly Bahia State, received Africans from Central West Africa until the middle of the 19th century (Bight of Benin and Bight of Biafra), justifying the frequencies of CAR and Benin haplotypes found in this population (19).

These findings may contribute to the investigation of slave trade routes in Brazil and African origins of the Bahian population that seems to be quite different to other Brazilian states and other world populations An increase in the number of samples analyzed will probably confirm a phenotypical difference among the sickle cell patients from Bahia and other patient groups worldwide.

\section{ACKNOWLEDGMENTS}

This study was funded in part by contract grant sponsor PAPES-FIOCRUZ; contract grant number: 0250250304; contract grant sponsor CNPq; contract grant number 521201/96-1; contract grant sponsor UNESCO/FAPESB; contract grant number 13/03 Protocol 1431030006830; contract grant sponsor Infra-Estrutura-FAPESB, and 
contract grant number 301/03 Protocol 1431030005540. We are grateful to Fabíola Nascimento Conceição from the Oswaldo Cruz Foundation, Salvador-Bahia, Brazil, for the English review.

\section{REFERENCES}

1. Pagnier RJ, Mears JG, Dunda-Belkhodja O, Schaefer-Rego KE, Beldjord C, Nagel RL, Labie D. Evidence for the multicentric origin of the sickle cell hemoglobin gene in Africa. Proc Natl Acad Sci USA 1984; 81(6):1771-1773.

2. Nagel RL. The origin of the Hemoglobin $S$ gene: clinical, genetic and anthropological consequences. Einstein Q J Biol Med 1984; 2:53-62.

3. Nagel RL, Steinberg MH. Genetics of the $\beta^{\mathrm{S}}$ gene: origins, genetic epidemiology, and epistasis in sickle cell anemia. In: Steinberg MH, Forget BG, Higgs DR, Nagel RL, eds. Disorders of Hemoglobin: Genetics, Pathophysiology, and Clinical Management. New York: Cambridge University Press, 2001;711-755.

4. Rahgozar S, Poorfathollah AA, Moafi AR, Old JM. $\beta^{S}$ gene in Central Iran is in linkage disequilibrium with the Indian-Arab haplotype. Am J Hematol 2000; 65(3):192-195.

5. Azevêdo ES. Subgroup studies of black admixture within a mixed population of Bahia, Brazil. Ann Hum Genet 1980; 44(Pt. 1):55-60.

6. Ramalho AS, Jorge RN, Oliveira JA, Pedreira DA. Hemoglobina S em recémnascidos Brazileiros. J Pediatr 1976; 41:9-10.

7. Azevêdo ES, Alves AFP, Silva MCBO, Souza MGF, Lima AMVMD, Azevêdo WC. Distribution of abnormal hemoglobins and glucose-6-phosphate dehydrogenase variants in 1200 school children of Bahia, Brazil. Am J Phys Anthropol 1980; 53(4):509-512.

8. Sutton M, Bouhassi EE, Nagel RL. Polymerase chain reaction amplification applied to the determination of $\beta$-like globin gene cluster haplotypes. Am J Hematol 1989; 32(1):66-69.

9. Steinberg MH, Embury SH. $\alpha$-Thalassemia in blacks: genetic and clinical aspects and interactions with the sickle hemoglobin gene. Blood 1986; 68(5):985-990.

10. Adekile AD, Tuli M, Haider MZ, Al-Zaabi K, Mohannadi S, Owunwanne A. Influence of $\alpha$-thalassemia trait on spleen function in sickle cell anemia patients with high Hb F. Am J Hematol 1996; 53(1):1-5.

11. Gonçalves MS, Bomfim GC, Maciel E, Cerqueira I, Lyra I, Zanette A, Bomfim G, Adorno EV, Albuquerque AL, Pontes A, Dupuit MF, Fernandes GB, dos Reis MG. $\beta^{\mathrm{S}}$-Haplotypes in sickle cell anemia patients from Salvador, Bahia, Northeastern Brazil. Braz J Med Biol Res 2003; 36(10):1283-1288.

12. Curtin PB. The slave trade of the nineteenth century. The Atlantic Slave Trade. Madison: The University of Wisconsin Press, 1969:231-264.

13. Lugo MV, Rodrígues-Larraldee A, Guerra DC. $\beta$-Globin gene cluster haplotypes as evidence of African gene flow to the northeastern coast of Venezuela. Am J Human Biol 2003; 15(1):29-37.

14. Arends A, Alvarez M, Velázquez D, Bravo M, Salazar R, Guevara JM, Castillo O. Determination of $\beta$-globin gene cluster haplotypes and prevalence of $\alpha$-thalassemia in sickle cell anemia patients in Venezuela. Am J Hematol 2000; 64(2):87-90. 
15. Magaña MT, Ongay Z, Tagle J, Bentura G, Cobián JG, Perea FJ, Casas-Castañeda M, Sánchez-López YJ, Ibarra B. Analysis of $\beta^{\mathrm{S}}$ and $\beta^{\mathrm{A}}$ genes in a Mexican population with African roots. Blood Cells Mol Dis 2002; 28(2):121-126.

16. Zago MA, Figueiredo MS, Ogo SH. Bantu $\beta^{\mathrm{S}}$ cluster haplotype predominates among Brazilian blacks. Am J Phys Anthropol 1992; 88(3):295-298.

17. Pante-De-Souza G, Mousinho-Ribeiro RC, Dos Santos EJM, Zago MA, Guerreiro JF. Origin of the Hemoglobin $\mathrm{S}$ gene in a northern Brazilian population: the combined effects of slave trade and internal migrations. Genet Mol Biol 1998; 21(4):1-9.

18. Verger P. Flux at Flux de la Traite des Négres Entre le Golfe de Benin at Bahia de Todos os Santos. Paris: Mouton Press, 1968.

19. Florentino M. Em Costas Negras. Rio de Janeiro: Companhia das Letras Press, 1997.

Received January 16, 2004

Accepted March 8, 2004 
Copyright of Hemoglobin is the property of Marcel Dekker Inc. and its content may not be copied or emailed to multiple sites or posted to a listserv without the copyright holder's express written permission. However, users may print, download, or email articles for individual use. 